\title{
Distribution of Baseline Sensitivities to Azoxystrobin Among Isolates of Plasmopara viticola
}

\author{
Francis P. Wong and Wayne F. Wilcox, Department of Plant Pathology, Cornell University, New York Agricul- \\ tural Experiment Station, Geneva 14456
}

\begin{abstract}
Wong, F. P., and Wilcox, W. F. 2000. Distribution of baseline sensitivities to azoxystrobin among isolates of Plasmopara viticola. Plant Dis. 84:275-281.

An excised leaf disc assay was developed for determining the sensitivity of isolates of Plasmopara viticola (causal agent of grapevine downy mildew) to the strobilurin fungicide azoxystrobin. Five repeated assays with the same five single-sporangiophore isolates showed that the technique yielded reproducible results; that is, coefficients of variation ranged from 4.0 to $20 \%$ (mean $12 \%$ ) for effective doses for $50 \%$ control $\left(\mathrm{ED}_{50}\right.$ values) based on disease incidence and from 4.4 to $14 \%$ (mean $8.1 \%$ ) for $\mathrm{ED}_{50}$ values based on disease severity. Then, the assay was applied to 81 single-sporangiophore isolates of $P$. viticola collected from 10 geographically distinct vineyards in western New York, providing a baseline distribution of sensitivities within this population. For disease incidence, individual $\mathrm{ED}_{50}$ values ranged from 0.05 to $0.94 \mu \mathrm{g} / \mathrm{ml}$ (mean $0.40 \mu \mathrm{g} / \mathrm{ml}$ ), whereas for disease severity they ranged from 0.04 to $0.78 \mu \mathrm{g} / \mathrm{ml}$ (mean 0.24 $\mu \mathrm{g} / \mathrm{ml})$. When 61 of these isolates were similarly tested at a single discriminatory dose of 0.50 $\mu \mathrm{g} / \mathrm{ml}$, azoxystrobin provided $61 \%$ control of disease incidence versus 41 and $1.1 \%$ control for trifloxystrobin and kresoxim-methyl, respectively; for disease severity (colony diameter), azoxystrobin provided $80 \%$ control versus 57 and $1.1 \%$ control for trifloxystrobin and kresoximmethyl, respectively. These results provide information that can be utilized in future monitoring of $P$. viticola resistance to azoxystrobin and indicate differences in the intrinsic activities of the three strobilurin fungicides against this pathogen.
\end{abstract}

The strobilurin fungicides represent a new, important class of chemicals for the management of a broad range of fungal diseases in agricultural production systems. These compounds are highly selective, site-specific molecules that inhibit mitochondrial respiration by blocking electron transfer within the mitochondrial $\mathrm{bc}_{1}$ complex $(4,5,31)$. The strobilurins are unique in that they are the first synthetic, site-specific compounds to provide significant control of plant diseases caused by pathogens from all three of the major groups of fungi (Oomycota, Ascomycota, and Basidiomycota; 1,2,11,12,34).

The risk of these plant pathogens developing resistance to the strobilurins is currently unclear. However, the introduction of selectively active, site-specific fungicides into agricultural production systems typically has been followed by the development of resistance to them by at least some target organisms $(7,26)$. Thus, in order to prolong the effectiveness of such compounds, fungicide resistance must be managed. An essential component of such management is the monitoring of fungal

Corresponding author: F. P. Wong

E-mail: fpw1@cornell.edu

Accepted for publication 23 November 1999.

Publication no. D-2000-0119-01R

(C) 2000 The American Phytopathological Society pathogen populations for their sensitivities to crop-protection compounds. These monitoring efforts should be based upon comparisons with baseline sensitivity data (i.e., sensitivity distributions determined before the widespread use of the new chemistries; 14,16,30) and the techniques must be suitably precise and reliable to detect relevant shifts in sensitivity within the population.

Azoxystrobin is a strobilurin fungicide that currently is used on a number of agronomic and horticultural crops worldwide. On grapevines, it is particularly useful in humid production regions, because it is the only currently available fungicide to provide effective control of downy mildew (Plasmopara viticola) in addition to powdery mildew (Uncinula necator), which are the two most important fungal diseases of this crop $(2,10,32,33)$. Downy mildew is a potentially destructive disease when warm, wet conditions occur during the production season, and much of the worldwide fungicide usage on grapevine is directed towards its control. However, the continued availability or utility of many current options for the fungicidal control of downy mildew is in question. For instance, captan and the ethylenebisdithiocarbamate (EBDC) fungicides are under increasing regulatory scrutiny (e.g., the United States Food Quality Protection Act of 1996), resistance to phenylamide fungicides (metalaxyl) was detected soon after their introduction in the early 1980s $(13,20)$, and copper-based fungicides are phytotoxic to some cultivars (29) and provide a heavy metal that is not degradable in vineyard soils. Thus, it is important to maintain the efficacy of new alternatives such as azoxystrobin (e.g., through resistance-management programs).

Therefore, the primary objectives of this study were to (i) develop a method for assaying the sensitivity of $P$. viticola isolates to azoxystrobin and (ii) utilize the technique to construct a baseline sensitivity distribution for this pathogen-fungicide interaction. A secondary objective was to use the technique to compare the intrinsic activity of azoxystrobin with those of two other strobilurin fungicides, kresoximmethyl and trifloxystrobin, which appear to provide less control of downy mildew under field conditions (33).

\section{MATERIALS AND METHODS}

Collection and maintenance of $P$. viticola isolates. In October 1997, samples of $P$. viticola were collected from 10 vineyards within a $7,000 \mathrm{~km}^{2}$ region of western New York, none of which had been treated previously with strobilurin fungicides. To reduce the probability of collecting multiple clonal isolates of the pathogen, single leaves were sampled from well-dispersed locations in the vineyard. Leaves were kept in individual plastic bags for transport to the lab, where lesions were induced to sporulate by incubating leaves overnight in darkness in a humid chamber. Resulting sporangia were transferred onto leaf discs obtained from greenhouse-grown Vitis vinifera $\mathrm{cv}$. Gewürtztraminer vines. Potted vines were maintained in the greenhouse at $27^{\circ} \mathrm{C}$ with $6 \mathrm{~h}$ of daily supplemental lighting and weekly fertilization. Fully expanded leaves, four to six leaf positions distal from the shoot tip, were surface disinfested for $90 \mathrm{~s}$ in $\mathrm{dH}_{2} \mathrm{O}$ containing $0.5 \%$ sodium hypochlorite and $0.1 \%$ Tween 20 (Sigma-Aldrich, St. Louis), triple rinsed in type $\mathrm{I} \mathrm{dH}_{2} \mathrm{O}$, and blotted dry between paper towels. Discs (9 $\mathrm{mm}$ in diameter) were removed from these leaves with a cork borer and placed into covered Petri dishes (60 $\mathrm{mm}$ in diameter) containing approximately $15 \mathrm{ml}$ of $1.5 \%$ granulated agar (Difco Laboratories, Detroit) amended with RAP agar $(30 \mu \mathrm{g} / \mathrm{ml}$ of rifampicin, $150 \mu \mathrm{g} / \mathrm{ml}$ of sodium ampicillin, and 5 $\mu \mathrm{g} / \mathrm{ml}$ of pimaricin; Sigma-Aldrich), with the abaxial surface exposed. After the transfer of sporangia, each leaf disc was overlaid with approximately $20 \mu \mathrm{l}$ of sterile 
$\mathrm{dH}_{2} \mathrm{O}$ and incubated overnight on the lab bench, in darkness, to allow infection. The next morning, excess water was removed from the leaf discs by vacuum aspiration. Leaf discs were then maintained in the Petri dishes at room temperature (20 to $25^{\circ} \mathrm{C}$ ) with 12 -h alternating periods of light (fluorescent) and dark.

Individual isolates were obtained by removing a single sporangiophore from the sporulating lesion that had formed on each disc 7 days after the initial transfer to the leaf discs, using \#5 fine tweezers (Fisher, Pittsburgh, PA) with the aid of a dissecting microscope. The sporangiophore and attached sporangia were transferred to a new leaf disc and infection was promoted as described above. For each isolate, the procedure was repeated three times in sequence to ensure purity. A total of 81 single-sporangiophore isolates of $P$. viticola were obtained in this manner. Each week for the duration of the experiment, individual isolates were maintained by bulk transfer of sporangia onto a new disc and repeating the post-inoculation procedures described above. When large numbers of sporangia were required for fungicide assays, individual isolates were amplified by inoculating the entire surface of a sterilized leaf section (approximately 60 by $30 \mathrm{~mm}$ ) using a single sporulating leaf disc. The inoculated leaf surface was overlaid with $500 \mu \mathrm{l}$ of sterile $\mathrm{dH}_{2} \mathrm{O}$, after which the leaf section was treated as described previously.

Fungicides. Technical-grade azoxystrobin (98\% active, Zeneca Ag Products, Richmond, CA), kresoxim-methyl (93\% active, BASF, Research Triangle Park, NC), and trifloxystrobin (96\% active, Novartis Crop Protection, Greensboro, NC) were used in all assays unless otherwise noted. The fungicides were dissolved in acetone to provide stock solutions containing $1,000 \mu \mathrm{g} / \mathrm{ml}$ of azoxystrobin and trifloxystrobin and $10,000 \mu \mathrm{g} / \mathrm{ml}$ of kresoxim-methyl. All stock solutions were stored at $-20^{\circ} \mathrm{C}$. For each assay, an aliquot of concentrated stock solution was added to sterile $\mathrm{dH}_{2} \mathrm{O}$ containing $0.005 \%$ Tween 20 to obtain the highest concentration of fungicide solution to be used for the assay. This solution was mixed for 30 min using a magnetic stir bar and plate to ensure a homogenous fungicide concentration. Then, serial dilutions were made in sterile $\mathrm{dH}_{2} \mathrm{O}$ containing $0.005 \%$ Tween 20 to obtain dilute solutions of the appropriate fungicide concentration. The maximum concentration of acetone used in dilute solution was $0.2 \%$. Acetone concentration was not corrected for and varied between serial dilutions.

Fungicide sensitivity assays. Assay variables. Preliminary experiments and published work with Uncinula necator $(6,8)$ and Guignardia bidwellii (19) have shown that grapevine leaves of different ages vary in their susceptibility to some fungal pathogens. To identify this potential source of variability and thereby reduce its effect in the fungicide sensitivity assays, leaves from different positions on greenhouse-grown cv. Gewürtztraminer vines were tested for their relative susceptibility to infection by $P$. viticola. Leaves were sorted by position into eight groups, from the third (first fully expanded) to tenth leaf distal from the shoot tip. Using the procedures described above, 20 discs from each group were prepared and placed into plastic Petri dishes (100 $\mathrm{mm}$ in diameter) containing approximately $25 \mathrm{ml}$ of RAP agar. Then, each disc was inoculated with a 10$\mu \mathrm{l}$ drop of sterile $\mathrm{dH}_{2} \mathrm{O}$ containing $1 \times 10^{4}$ sporangia/ml of a single isolate of $P$. viti-

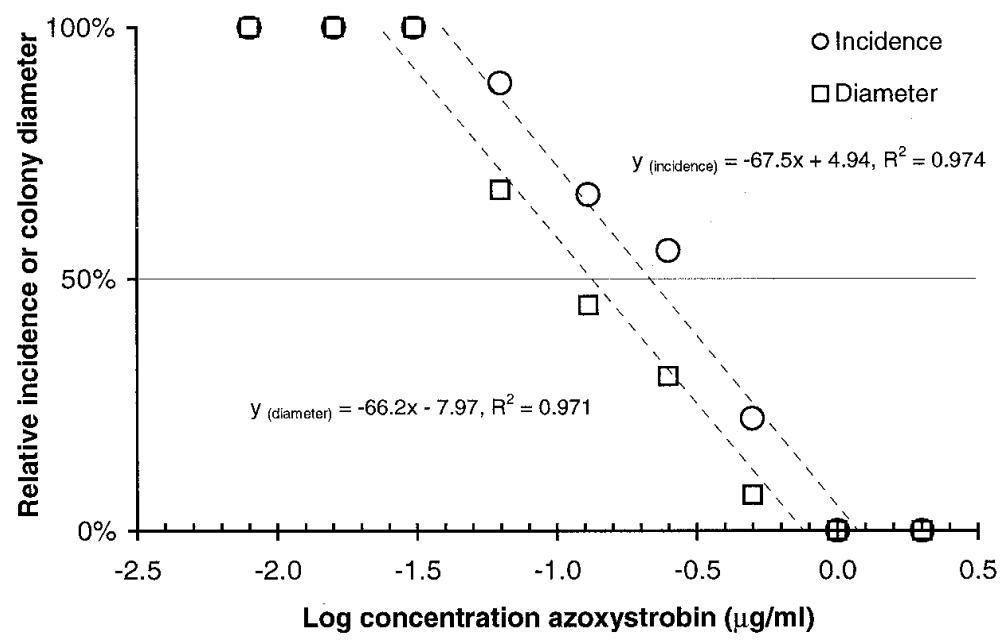

Fig. 1. Typical dose-response curves of Plasmopara viticola to azoxystrobin: obtained for isolate CL-5. Dose-response curves were generated based upon disease incidence or mean colony diameter of $P$. viticola 7 days after inoculation onto 20 azoxystrobin-treated grape leaf discs per concentration. Both values are expressed as percentages relative to the check treatment. Log $50 \%$ effective doses $\left(\mathrm{ED}_{50}\right.$ values) were determined by calculating the concentration of azoxystrobin at $50 \%$ relative incidence or colony diameter, based upon a straight line regressed through the linear portion of the sigmoidal curves generated in the assay for each of the 81 isolates tested. cola (DM-15). Inoculum concentration was quantified by the use of a hemacytometer (Fisher), and dilutions were made with sterile $\mathrm{dH}_{2} \mathrm{O}$ in order to obtain the appropriate concentration. All discs were incubated at room temperature with alternating periods of light and dark, as described above. At 7 days after inoculation, disease incidence was measured as the percentage of leaf discs with sporulating colonies, determined on the basis of visual detection with the aid of a stereomicroscope at $32 x$ magnification. Under these assay conditions, the disease manifested itself as single, discreet sporulating colonies of circular shape on the leaf discs. The test was repeated three times. Results were analyzed by one-way analysis of variation (ANOVA) with multiple comparisons using Fisher's least significant difference (LSD; version 12.10, MINITAB, State College, PA).

The same procedures were used to determine an appropriate inoculum concentration for use in the sensitivity assays. Discs were prepared from cv. Gewürtztraminer leaves of common maturity, the discs were randomized, and 20 discs each were inoculated with a $10-\mu \mathrm{l}$ drop of sterile $\mathrm{dH}_{2} \mathrm{O}$ containing $1 \times 10^{3}, 1 \times 10^{4}$, or $1 \times$ $10^{5}$ sporangia/ml of $P$. viticola isolate DM15 , with the inoculum concentration quantified as described above. Disease incidence was determined 7 days later, as described above. The test was repeated three times. Results were analyzed by oneway ANOVA with multiple comparisons using Fisher's LSD.

Stangellini (28) has described the deleterious effect of surfactants on the zoospores of the Oomycete pathogens, Plasmopara

Table 1. Effect of leaf age on the susceptibility of excised cv. Gewürtztraminer grape leaf discs to infection by Plasmopara viticola

\begin{tabular}{lcc}
\hline & \multicolumn{2}{c}{ Disease incidence (\%) } \\
\cline { 2 - 3 } Leaf position $^{\mathbf{x}}$ & Mean $^{\mathbf{y}}$ & SE $^{\mathbf{z}}$ \\
\hline 3 & $100 \mathrm{a}$ & 0.0 \\
4 & $100 \mathrm{a}$ & 0.0 \\
5 & $100 \mathrm{a}$ & 0.0 \\
6 & $98 \mathrm{a}$ & 2.9 \\
7 & $82 \mathrm{~b}$ & 10.0 \\
8 & $67 \mathrm{~b}$ & 7.6 \\
9 & $40 \mathrm{c}$ & 10.0 \\
10 & $35 \mathrm{c}$ & 8.7 \\
\hline
\end{tabular}

${ }^{x}$ Position distal from the shoot tip, with position 3 being the first fully expanded leaf, and increasing position number reflecting increasing leaf age.

${ }^{y}$ Mean value from three independent trials, with 20 replicate leaf discs per treatment in each trial. Leaf discs were inoculated with a $10-\mu$ drop containing $1 \times 10^{4}$ sporangia/ml and incubated at room temperature, with 12-h alternating periods of light and dark, for 7 days prior to evaluation. Means not followed by a common letter are significantly different $(P \leq 0.05)$ according to Fisher's least significant difference.

${ }^{z}$ Standard error of the mean for three independent trials. 
lactucae-radicis, Phytophthora capsici, and Pythium aphanidermatum. To ensure that our assay conditions did not compromise the infectivity of Plasmopara viticola zoospores, we tested the effects of the constant concentration of $0.005 \%$ Tween 20 and the highest concentration of acetone $(0.2 \%)$ used in the assays. Cv. Gewürtztraminer leaf discs were prepared as described above, using leaves of common maturity, and randomized. A total of 10 discs each were soaked for $1 \mathrm{~h}$ in $50 \mathrm{ml}$ of sterile $\mathrm{dH}_{2} \mathrm{O}$, sterile $\mathrm{dH}_{2} \mathrm{O}$ containing $0.005 \%$ Tween 20 , or sterile $\mathrm{dH}_{2} \mathrm{O}$ containing $0.2 \%$ acetone and $0.005 \%$ Tween 20, with regular agitation. Afterwards, discs were inoculated with $P$. viticola isolate DM-15 and disease incidence and severity were assayed, using the methods described below. Results were analyzed by one-way ANOVA with multiple comparisons using Fisher's LSD.

Determination of baseline distribution of P. viticola sensitivities to azoxystrobin. Discs were prepared as above, randomized, and placed into beakers containing $50 \mathrm{ml}$ of each fungicide solution. Azoxystrobin concentrations ranged from 2.0 to 0.008 $\mu \mathrm{g} / \mathrm{ml}$ at twofold dilutions; the check treatment contained $0.2 \%$ acetone and $0.005 \%$ Tween 20 only. After a 1-h treatment period with regular agitation to insure uniform coverage, the leaf discs were removed from the beakers and blotted dry with paper towels, then transferred to covered Petri dishes (100 $\mathrm{mm}$ in diameter) containing approximately $25 \mathrm{ml}$ of RAP agar. A total of 20 leaf discs per plate were used for each isolate $\times$ concentration combination. Each leaf disc was inoculated 24 $\mathrm{h}$ later with a $10-\mu \mathrm{l}$ drop of a suspension containing $1 \times 10^{4}$ sporangia/ml obtained from a 7-day-old culture of a test isolate. The discs were incubated for 7 days after inoculation as described above, after which disease incidence and severity were determined. Disease incidence was measured as the percentage of sporulating colonies on leaf discs and disease severity was calculated as a function of the mean colony diameter. The diameter of each sporulating colony was measured using an ocular micrometer on a stereomicroscope at $32 \times$ magnification. The effective doses for $50 \%$ control of both disease incidence and severity $\left(\mathrm{ED}_{50}\right.$ values) were calculated by plotting the percent incidence and mean colony diameter relative to the check values versus the log of the azoxystrobin concentration. Linear regression was performed through the linear portion of the sigmoidal curve (Fig. 1), and the concentration of azoxystrobin for $50 \%$ incidence or severity was determined (Microsoft Excel 7.0, Microsoft Corp., Seattle, WA). $\mathrm{ED}_{50}$ values are reported as actual (antilog) concentrations.

In preliminary experiments, each of five different isolates of $P$. viticola (CL-1, CL2, CL-3, CL-5, and CL-6) were tested five different times to determine the reproducibility of the assay, and $\mathrm{ED}_{50}$ values were calculated for each of the five tests as described. The mean, standard error, and $95 \%$ confidence intervals of the $\mathrm{ED}_{50}$ values were determined based upon the (normally distributed) log-transformed $\mathrm{ED}_{50}$ values for each of the five tested isolates. Coefficients of variability (the absolute value of [standard error of the mean/mean]) were calculated as a measure of assay reproducibility based upon these values. $\mathrm{ED}_{50}$ values were determined for evaluations made 5, 6, 7, 8, and 9 days after inoculation. There was no significant effect of these incubation periods on the calculated $\mathrm{ED}_{50}$ value (one-way ANOVA, $P=0.81$ ); thus, evaluation at 7 days post inoculation was chosen as the assay standard for sake of convenience.

After the assay reproducibility was known, the test was repeated once against all 81 isolates of $P$. viticola. For each run of the experiment, approximately five isolates were assayed, using the entire range of concentrations and 20 replicate cv. Gewürtztraminer leaf discs for each isolate $\times$ concentration combination. Histograms were constructed for the $\log \mathrm{ED}_{50}$ values, based upon both disease incidence and severity, to reflect the baseline sensitivity distribution of $P$. viticola to azoxystrobin.

Comparison of intrinsic activities of azoxystrobin, kresoxim-methyl, and trifloxystrobin. In order to compare the intrinsic activity of the three strobilurin fungicides

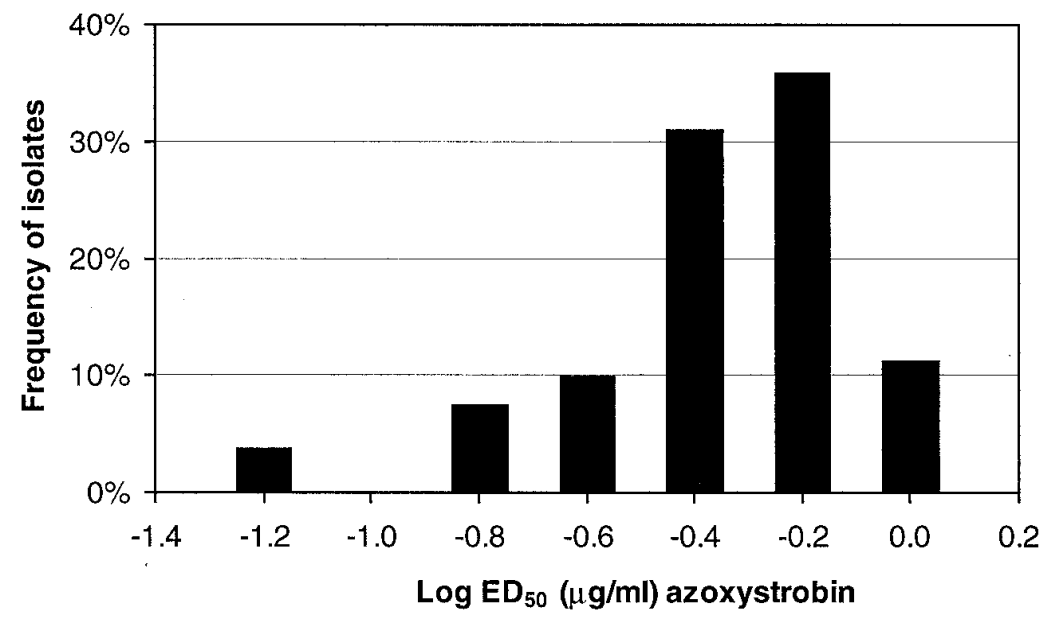

Fig. 2. Baseline sensitivity distribution of 81 isolates of Plasmopara viticola to azoxystrobin based upon disease incidence. $\log 50 \%$ effective dose $\left(\mathrm{ED}_{50}\right)$ values for individual isolates are organized within discrete categories, based upon the least significant difference of $0.20 \log$ units $(\alpha=0.05)$.

Table 2. Reproducibility of effective doses for $50 \%$ control $\left(\mathrm{ED}_{50}\right.$ values) determined for azoxystrobin against five isolates of Plasmopara viticola using an excised-leaf-disc assay ${ }^{x}$

\begin{tabular}{|c|c|c|c|c|c|c|}
\hline \multirow[b]{2}{*}{ Isolate } & \multicolumn{3}{|c|}{$\mathrm{ED}_{50}(\mu \mathrm{g} / \mathrm{ml})$, incidence $^{\mathrm{y}}$} & \multicolumn{3}{|c|}{$\mathrm{ED}_{50}(\mu \mathrm{g} / \mathrm{ml})$, severity $^{\mathrm{z}}$} \\
\hline & Mean & $95 \% \mathrm{CI}$ & $\mathrm{CV}$ & Mean & $95 \% \mathrm{CI}$ & $\mathbf{C V}$ \\
\hline CL-1 & 0.18 & $(0.12$ to 0.22$)$ & 0.12 & 0.12 & (0.09 to 0.14$)$ & 0.06 \\
\hline CL-2 & 0.18 & $(0.13$ to 0.21$)$ & 0.10 & 0.11 & (0.08 to 0.13$)$ & 0.08 \\
\hline CL-3 & 0.34 & (0.22 to 0.42$)$ & 0.20 & 0.19 & (0.12 to 0.24$)$ & 0.14 \\
\hline CL-5 & 0.25 & (0.18 to 0.29$)$ & 0.12 & 0.12 & ( 0.10 to 0.13$)$ & 0.04 \\
\hline CL-6 & 0.23 & (0.20 to 0.24$)$ & 0.04 & 0.15 & (0.11 to 0.17 ) & 0.07 \\
\hline Mean & $\ldots$ & $\ldots$ & 0.12 & $\ldots$ & $\ldots$ & 0.08 \\
\hline
\end{tabular}

${ }^{\mathrm{x}}$ Mean $=$ mean $\mathrm{ED}_{50}$ value based upon five repeated assays; $95 \% \mathrm{CI}=$ the $95 \%$ confidence interval based upon log-transformed $\mathrm{ED}_{50}$ values with values expressed as the antilog of the calculated interval; $\mathrm{CV}=$ the coefficient of variation, expressed as the absolute value of (standard of error of the mean of $\log \mathrm{ED}_{50}$ values)/(mean of $\log \mathrm{ED}_{50}$ values).

${ }^{y} \mathrm{ED}_{50}$ values determined for the incidence of infection on 20 replicate grape leaf discs per concentration tested ( 0.0 to $2.0 \mu \mathrm{g} / \mathrm{ml}$ of azoxystrobin). Leaf discs were inoculated with a $10-\mu$ drop containing $1 \times 10^{4}$ sporangia/ml and incubated at room temperature, with 12 -h alternating periods of light and dark, for 7 days prior to evaluation.

${ }^{\mathrm{z}} \mathrm{ED}_{50}$ values determined for the mean colony diameter on 20 replicate grape leaf discs per concentration tested. 
against $P$. viticola, the effect of a single discriminatory dose of each compound $(0.5$ $\mu \mathrm{g} / \mathrm{ml}$ ) was evaluated against 61 isolates using the methods described above. Additionally, a dose of $3.0 \mu \mathrm{g} / \mathrm{ml}$ of kresoximmethyl was tested against the 61 isolates. Relative incidence (RI) and relative growth (RG) values were calculated for each compound by comparing the percentage of diseased leaf discs or mean colony diameters, respectively, to the corresponding value for the check treatment for each isolate. This test was performed once for each isolate for each of the four fungicide treatments used. RI and RG values for the treatments were analyzed using one-way ANOVA with multiple comparisons using Fisher's LSD.

\section{RESULTS}

Fungicide sensitivity assays. Leaf age effects. Leaf position had a significant effect on the susceptibility of the tissue to infection by $P$. viticola (Table 1). Over the course of three independent repeats of the experiment, all of the discs from leaf positions 3, 4, and 5 became infected, as did virtually all of those from leaf position 6 . In contrast, the results were more variable and leaves appeared to become progressively more resistant to infection at the older positions, with mean incidences of infection ranging from $82 \%$ at leaf position 7 down to $35 \%$ at position 10 (Table 1). Therefore, we chose to use only leaves from position 5 in the fungicide sensitivity assays. These leaves were more resistant to

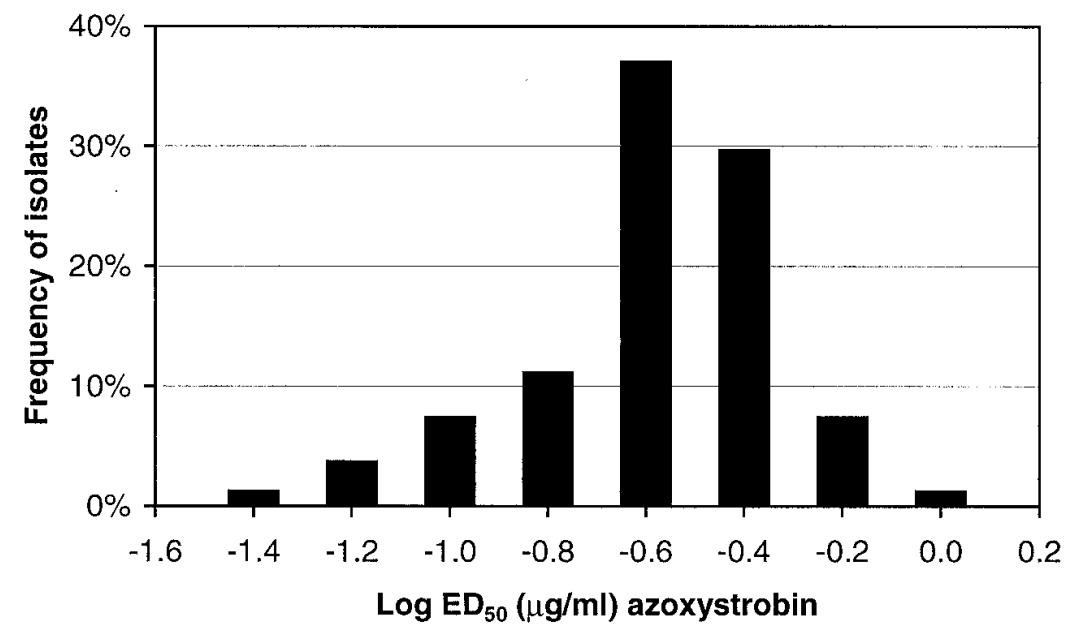

Fig. 3. Baseline sensitivity distribution of 81 isolates of Plasmopara viticola to azoxystrobin based upon disease severity, as measured by mean colony diameter. Log $50 \%$ effective dose $\left(\mathrm{ED}_{50}\right)$ values for individual isolates are organized within discreet categories, based upon the least significant difference of $0.20 \log$ units $(\alpha=0.05)$.

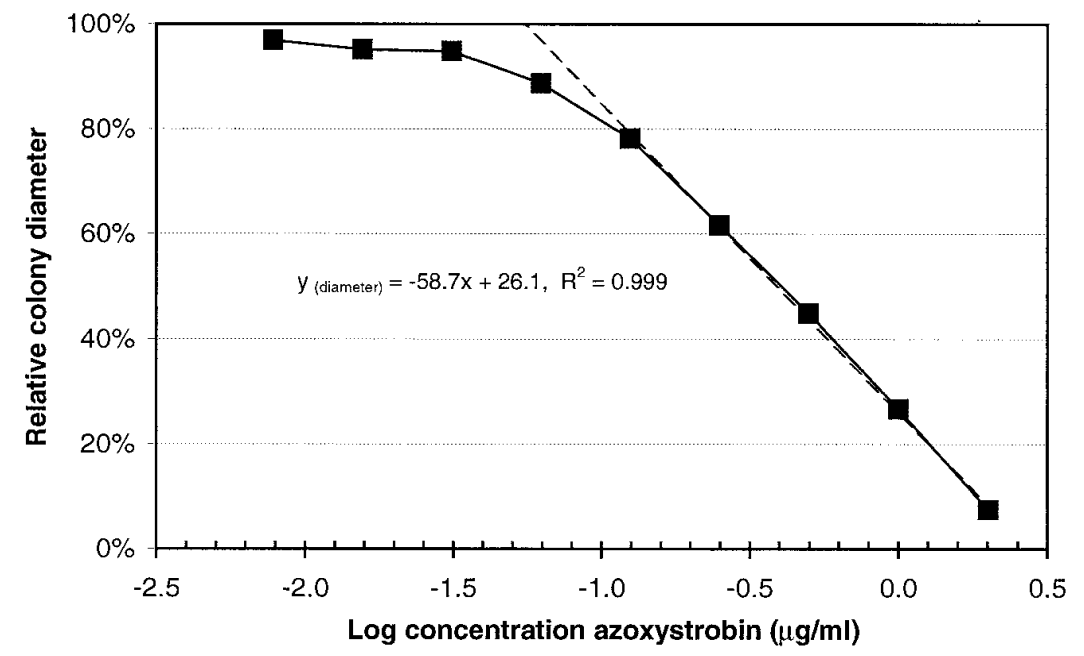

Fig. 4. Effect of azoxystrobin concentration on colony expansion for 81 isolates of Plasmopara viticola. For each isolate, 20 replicate grape leaf discs per concentration were inoculated with a $10-\mu 1$ droplet containing $1 \times 10^{4}$ sporangia/ml and colony diameters were measured 7 days later with an ocular micrometer at $32 \times$ magnification. Mean values were determined only for those discs that showed symptoms, and were expressed as a percentage relative to the mean diameter for the check treatment. Linear regression was performed for relative colony diameters at concentrations ranging from 0.13 to $2.0 \mu \mathrm{g} / \mathrm{ml}$.

desiccation and the physical rigors of the assay process than the younger leaves, and were more temporally removed from the onset of age-dependent resistance than those at position 6 .

Inoculum concentration effects. Using leaves from position 5 , inoculum concentrations of $1 \times 10^{4}$ and $1 \times 10^{5}$ sporan$\mathrm{gia} / \mathrm{ml}$ each provided a mean infection incidence of $98 \%$ over the course of the three repeated experiments. In contrast, inoculations with $1 \times 10^{3}$ sporangia/ml produced a mean infection incidence of only $62 \%$. Thus, $1 \times 10^{4}$ sporangia/ml was chosen as the inoculum concentration for use in the assays, because it combined technical expediency with consistency of results.

Effects of acetone and Tween 20. Relative to the sterile $\mathrm{dH}_{2} \mathrm{O}$ control, there was no effect on disease incidence or severity when leaf discs were treated with $0.005 \%$ Tween 20 with or without $0.2 \%$ acetone prior to inoculation with a suspension containing $1 \times 10^{4}$ sporangia/ml. In all three trials, $100 \%$ of the discs in each treatment became infected, and there was no significant difference among treatments in mean lesion diameter $(P=0.31$, data not shown).

Assay reproducibility. For the five isolates examined in five repeated runs of the assay, the coefficients of variation, based upon log-transformed $\mathrm{ED}_{50}$ values, ranged from 4 to $20 \%$ with respect to disease incidence and from 4 to $14 \%$ with respect to disease severity for each isolate. The mean coefficients of variation based upon disease incidence and severity were 12 and $8.1 \%$, respectively (Table 2). The $95 \%$ confidence interval ranged from 11 to $35 \%$ of the mean $\mathrm{ED}_{50}$ value with respect to disease incidence and from 17 to $37 \%$ of the mean $\mathrm{ED}_{50}$ value with respect to disease severity (Table 2). The LSD for mean $\mathrm{ED}_{50}$ values, based upon log-transformed values, was $0.20 \log$ units with respect to both disease incidence and severity $(\alpha=$ 0.05).

Baseline distribution of $\boldsymbol{P}$. viticola sensitivities to azoxystrobin. For the 81 isolates screened for their sensitivity to azoxystrobin, the mean $\mathrm{ED}_{50}$ value based upon disease incidence was $0.40 \mu \mathrm{g} / \mathrm{ml}$. Individual $\mathrm{ED}_{50}$ values ranged from a maximum of $0.94 \mu \mathrm{g} / \mathrm{ml}$ to a minimum of 0.050 $\mu \mathrm{g} / \mathrm{ml}$, and thus were separated by a factor of 19 (Fig. 2). The mean $\mathrm{ED}_{50}$ value based upon disease severity (colony diameter) was $0.24 \mu \mathrm{g} / \mathrm{ml}$. Individual $\mathrm{ED}_{50}$ values ranged from a maximum of $0.78 \mu \mathrm{g} / \mathrm{ml}$ to a minimum of $0.037 \mu \mathrm{g} / \mathrm{ml}$ and, thus, were separated by a factor of 21 (Fig. 3).

Effect of azoxystrobin on colony expansion. When calculating mean colony diameters as a measure of disease severity, uninfected leaf discs were assigned a value of zero. To ensure that the reductions in disease severity values attributed to azoxystrobin treatments were not merely re- 
flections of reduced disease incidence, additional calculations were made to evaluate the effect of the fungicide on expansion of $P$. viticola colonies by determining mean colony diameters for infected leaf discs only. These calculations showed a strongly linear effect of azoxystrobin dose (log) on colony expansion at concentrations within the range of 0.13 to 2.0 $\mu \mathrm{g} / \mathrm{ml}$ (Fig. 4).

Comparison of intrinsic activities of azoxystrobin, kresoxim-methyl and trifloxystrobin. At a concentration of 0.5 $\mu \mathrm{g} / \mathrm{ml}$, the mean RI values were $0.39,0.59$, and 0.99 for azoxystrobin, trifloxystrobin, and kresoxim-methyl, respectively, whereas the mean RG values were $0.20,0.43$, and 0.99 (Fig. 5). For both parameters, differences in mean values were significant
$(P<0.05$, Fisher's LSD) in comparisons between azoxystrobin versus trifloxystrobin and kresoxim-methyl, and between trifloxystrobin versus kresoxim-methyl. Some activity of kresoxim-methyl was detected when the dose of this fungicide was increased to $3.0 \mu \mathrm{g} / \mathrm{ml}$, although the mean RI and RG values of 0.80 and 0.78 , respectively, were still significantly higher than those of the other two fungicides at the lower dose $(P<0.05$, Fisher's LSD for both comparisons).

Concentrations higher than $0.5 \mu \mathrm{g} / \mathrm{ml}$ of trifloxystrobin and $3.0 \mu \mathrm{g} / \mathrm{ml}$ of kresoximmethyl resulted in acute phytotoxicity to the leaf discs under the assay conditions, and therefore were not used. Phytotoxicity was manifested as a rapid necrosis of the leaf tissue at the leaf disc margins within
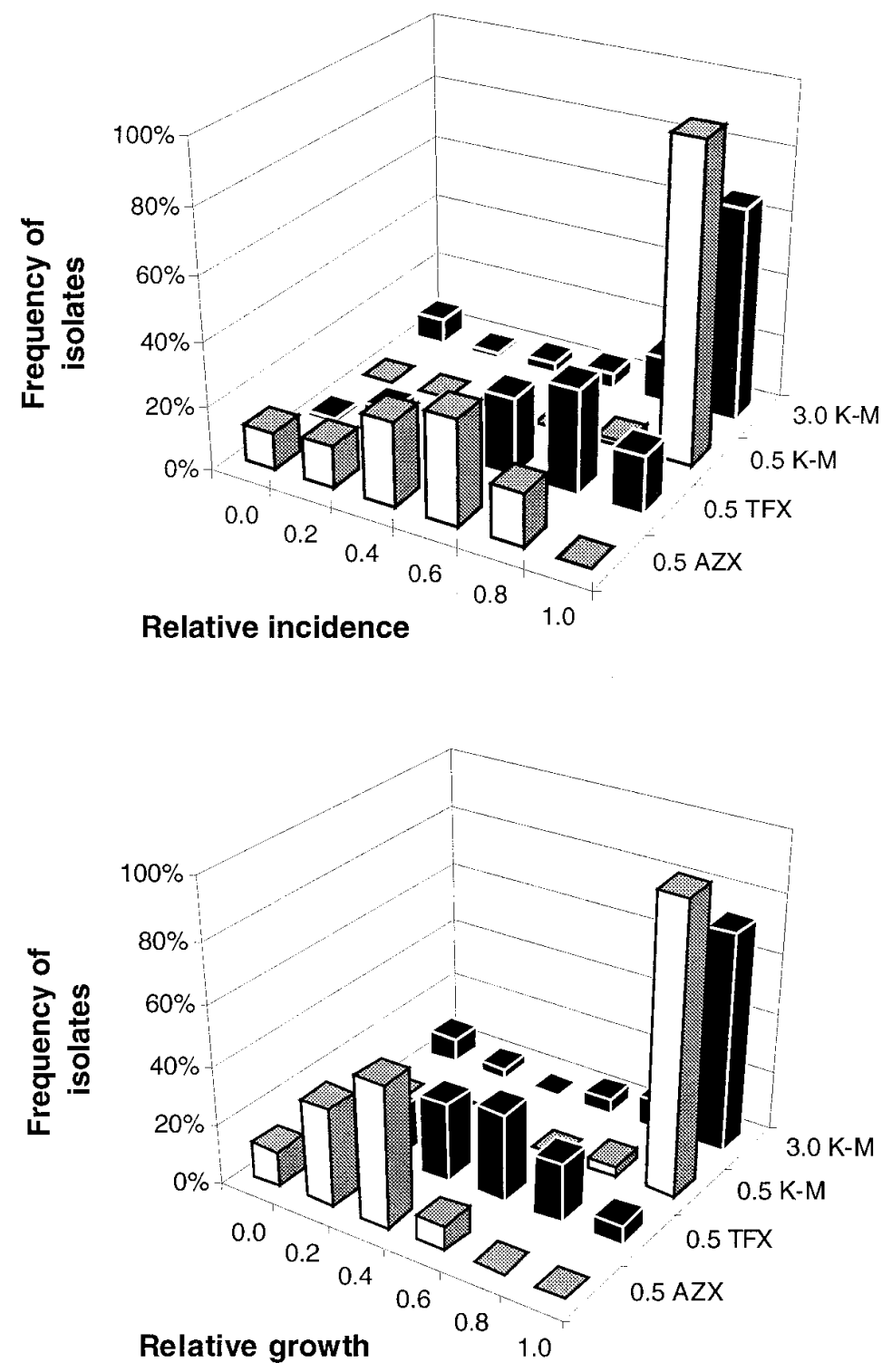

Fig. 5. Comparative intrinsic activities of $0.5 \mu \mathrm{g} / \mathrm{ml}$ of azoxystrobin $(0.5 \mathrm{AZX}), 0.5 \mu \mathrm{g} / \mathrm{ml}$ of trifloxystrobin ( $0.5 \mathrm{TFX}), 0.5 \mu \mathrm{g} / \mathrm{ml}$ of kresoxim-methyl $(0.5 \mathrm{~K}-\mathrm{M})$, and $3.0 \mu \mathrm{g} / \mathrm{ml}$ of kresoxim-methyl (3.0 K-M) against 61 isolates of Plasmopara viticola. Evaluations were based upon the growth of 61 Plasmopara viticola isolates on 20 replicate grape leaf discs per treatment, 7 days after inoculation with a 10- $\mu$ l drop containing $1 \times 10^{4}$ sporangia/ml. Results are expressed as a frequency distribution of the relative incidence of infected leaf discs and the relative growth of $P$. viticola colonies.
$24 \mathrm{~h}$, followed by the collapse of the leaf disc within $48 \mathrm{~h}$. Concentrations as high as $8.0 \mu \mathrm{g} / \mathrm{ml}$ of azoxystrobin did not result in any observable phytotoxicity under the assay conditions.

\section{DISCUSSION}

In this study, we have developed a repeatable method of known precision for assaying the sensitivity of $P$. viticola isolates to azoxystrobin, and have employed it to generate the first published baseline distribution of sensitivities to a strobilurin fungicide for this pathogen. Individual clonal isolates were utilized in order to detect an unbiased range of sensitivities within the sampled $P$. viticola population $(17,18)$, and the sample size of 81 isolates was large enough to represent this range among $95 \%$ of the population with $>95 \%$ confidence (21). Therefore, these results can be used in the future to monitor potential shifts in azoxystrobin sensitivity among $P$. viticola populations (e.g., to periodically assess the success of resistancemanagement programs or to evaluate practical resistance; 15,17) as a potential cause of unexplained control failures.

Calculated $\mathrm{ED}_{50}$ values were similar whether they were based upon measures of disease incidence or severity, as was reproducibility of the assay. Thus, both criteria appear to be similar in reliability, but the determination of disease incidence was far faster and less labor intensive than measurements of individual colony diameters with an ocular micrometer. Strobilurins are strong inhibitors of fungal spore germination $(11,23)$, but in vitro tests of spore germination do not provide an adequate means of assaying fungal individuals for their sensitivities to these materials $(22,36)$. However, qualitative determinations of disease occurrence (i.e., disease incidence assessments) might actually be providing an indirect measure of spore germination, appressorium formation, or cuticle penetration that is relevant in vivo. In contrast, demethylation inhibitor (DMI) fungicides do not inhibit these processes (25), and assays for sensitivities to these materials have necessarily focused upon quantitative measurements of pathogen growth or disease severity $(8,27,35)$. Calculations for the effect of azoxystrobin on colony expansion indicate that this fungicide is active both in the prevention of infection and in restricting the mycelial growth of $P$. viticola when infections become established, indicating that azoxystrobin can affect multiple stages of the fungal life cycle.

For measures of both disease incidence and severity, the baseline distributions of sensitivity for our sample population of $P$. viticola were unimodal and described an approximate 20 -fold range in $\mathrm{ED}_{50}$ values, similar to the previously-described narrow range of sensitivity of Mycosphaerella graminicola to azoxystrobin (9) and Ven- 
turia inequalis to kresoxim-methyl (22). This is contrasted by the much wider distribution of sensitivities to the DMI fungicides for several pathogens, including Venturia inaequalis (16) and Uncinula necator $(8,35)$, or to azoxystrobin for Phytophthora infestans (9). The baseline sensitivity distribution that we obtained appears to be consistent with previously reported $\mathrm{ED}_{50}$ values of $1.0 \mu \mathrm{g} / \mathrm{ml}$ or less for azoxystrobin against $P$. viticola (12).

Although we originally intended to develop a methodology that would allow us to evaluate the baseline sensitivity distributions for $P$. viticola to kresoxim-methyl, trifloxystrobin, and azoxystrobin, phytotoxicity problems with the former two compounds prevented us from accomplishing this goal. It is apparent that the method developed in this study is best suited for azoxystrobin or other compounds that do not cause acute phytotoxicity to the leaf discs under our assay conditions. Although a number of modifications were attempted to reduce the phytotoxicity exhibited by kresoxim-methyl and trifloxystrobin, including the reduction of soaking time in fungicide solution and the treatment of whole leaves in solution before the excision of leaf discs, none were satisfactory. It appears that the basis for phytotoxicity by kresoxim-methyl and trifloxystrobin is the contact of the cut leaf-disc edges with concentrations of these compounds exceeding 3.0 and 0.5 $\mu \mathrm{g} / \mathrm{ml}$, respectively, because necrosis always occurred first at the cut edges and spread inward. The biochemical mechanism of action of strobilurins against mitochondrial target sites appears to be nonspecies specific (24); therefore, it seems feasible that introduction of the compounds at these concentrations into the leaf mesophyll via the cut leaf surface might result in levels that cannot be metabolized sufficiently to an inactive form $(3,24)$ before cytotoxic effects on the plant cells are realized. Thus, it is possible that the limitations of our assay method imposed by phytotoxicity might be overcome by further refinements that we did not pursue.

Through the restricted use of leaf-disc assays, we were able to identify clear differences in the intrinsic activities of the three strobilurin fungicides examined against $P$. viticola. However, these data are supported only in part by those obtained by Wilcox et al. (33) in a recent field trial examining the same active ingredients. Using current commercial formulations of azoxystrobin (200 g/ha), kresoxim-methyl $(145 \mathrm{~g} / \mathrm{ha})$, and trifloxystrobin $(73 \mathrm{~g} / \mathrm{ha})$, they obtained 93,44 , and $14 \%$ control of downy mildew incidence and 99,82 , and $57 \%$ control of disease severity for the three respective compounds. Thus, whereas azoxystrobin provided superior results using both laboratory and field assessments, the relative field performances of the other two materials would not have been predicted by the leaf disc assay. Although this discrepancy can be partially explained by the differential dosages used in the field trial relative to the leaf-disc assay, it is likely that factors other than intrinsic activity (e.g., volatility, mobility in plant tissues, persistence, and degradation) also affect the performance of these compounds under field conditions.

\section{ACKNOWLEDGMENTS}

We thank H. N. Burr and C. S. Leung for their assistance in performing laboratory assays; J. A. Burr, L. E. Hoffman, and D. G. Riegel for technical support; and W. Köller for insight and advice.

\section{LITERATURE CITED}

1. Ammerman E., Lorenz, G., Schelberger, K., Wenderoth, B., Sauter, H., and Rentzea, C. 1992. BAS $490 \mathrm{~F}-\mathrm{A}$ broad-spectrum fungicide with a new mode of action. Pages 403410 in: Brighton Crop Protection Conference-Pests and Diseases-1992, vol. 1. Lavenham Press, Lavenham, Suffolk, UK.

2. Baldwin, B. C., Clough, J. M., Godfrey, C. R. A., Godwin, J. R., and Wiggins, T. E. 1996. The discovery and mode of action of ICIA5504. Pages 69-78 in: Modern Fungicides and Antifungal Compounds. H. Lyr, P. E. Russell, and H. D. Sisler, eds. Intercept, Andover, Hants, UK.

3. Bartlett, D. W., and Stalker, A. 1996. Metabolism of strobilurin analogues in wheat: Determination using a bioautography assay. Pages 101-104 in: Modern Fungicides and Antifungal Compounds. H. Lyr, P. E. Russell, and H. D. Sisler, eds. Intercept, Andover, Hants, UK.

4. Becker, W. F., von Jagow, G., Anke, T., and Steglich, W. 1981. Oudemansin, strobilurin A, strobilurin B, and myxothiazole: New inhibitors of the $b_{1}$ segment of the respiratory chain with an E- $\beta$-methoxyacrylate system as a common structural element. FEBS Lett. 132:329-333

5. Brandt, U., Schaegger, H., and von Jagow, G. 1988. Characterization of binding of the methoxyacrylate inhibitors to mitochondrial cytochrome c reductase. Eur. J. Biochem. 173:499-506.

6. Doster, M. A., and Schnathorst, W. C. 1985. Effects of leaf maturity and cultivar resistance on development of the powdery mildew fungus on grapevines. Phytopathology 75:318-321.

7. Eckert, J. W. 1988. Historical development of fungicide resistance in plant pathogens. Pages 1-3 in: Fungicide Resistance in North America. C. J. Delp, ed. APS Press, St. Paul, MN.

8. Erickson, E. O., and Wilcox, W. F. 1997. Distributions of sensitivities to three sterol demethylation inhibitor fungicides among populations of Uncinula necator sensitive and resistant to triadimefon. Phytopathology 87:784-791.

9. Gisi, U., Hermann, D., Ohl, L., and Steden, C. 1997. Sensitivity profiles of Mycosphaerella graminicola and Phytophthora infestans populations to different classes of fungicides. Pestic. Sci. 51:290-298.

10. Godwin, J. R., Anthony, V. M., Clough, J. M., and Godfrey, C. R. A. 1992. ICI A5504 a novel broad-spectrum systemic beta methoxyacrylate fungicide. Pages 435-442 in: Brighton Crop Protection Conference-Pests and Diseases-1992, vol. 1. Lavenham Press, Lavenham, Suffolk, UK.

11. Gold, R. E., Ammerman, E., Koehl, H., Leinhos, G. M. E., Lorenz, G., Speakman, J. B., Stark-Urnau, M., and Sauter, H. 1996. The synthetic strobilurin BAS $490 \mathrm{~F}$ : Profile of a modern fungicide. Pages 79-92 in: Modern Fungicides and Antifungal Compounds. $\mathrm{H}$.
Lyr, P. E. Russell, and H. D. Sisler, eds. Intercept, Andover, Hants, UK.

12. Heaney, S. P., and Knight, S. C. 1994. ICIA5504: A novel broad-spectrum systemic fungicide for use on fruit, nut and horticultural crops. Pages 509-516 in: Brighton Crop Protection Conference-Pests and Diseases1994, vol. 2. Major Print, Nottingham, UK.

13. Hewitt, W. B., and Pearson, R. C. 1988. Downy mildew. Pages 11-13 in: Compendium of Grape Diseases. R. C. Pearson and A. C. Goheen, eds. APS Press, St. Paul, MN.

14. Justum, A. R., Heaney, S. P., Perrin, B. M., and Wege, P. J. 1998. Pesticide resistance: Assessment of risk and implementation of effective management strategies. Pestic. Sci 54:435-446.

15. Köller, W. 1991. Fungicide resistance in plant pathogens. Pages 679-720 in: CRC Handbook of Pest Management in Agriculture. Vol. 2. D. Pimentel, ed. CRC Press, Boca Raton, FL.

16. Köller, W., Parker, D. P., and Reynolds, K. L. 1991. Baseline sensitivities of Venturia inaequalis to sterol demethylation inhibitors. Plant Dis. 75:726-728.

17. Köller, W., and Scheinpflug, H. 1987. Fungal resistance to sterol biosynthesis inhibitors: A new challenge. Plant Dis. 71:1066-1074.

18. Köller, W., and Wilcox, W. F. 1999. Quantification, persistence, and status of dodine resistance in New York and Michigan orchard populations of Venturia inaequalis. Plant Dis. 83:66-70.

19. Kuo, K., and Hoch, H. C. 1996. The parasitic relationship between Phyllosticta amepelicida and Vitis vinifera. Mycologia 88:626-634.

20. Leroux, P., and Clerjeau, M. 1985. Resistance of Botrytis cinerea and Plasmopara viticola to fungicides in French vineyards. Crop Prot. 4:137-160.

21. Leung, H., Nelson, R. J., and Leach, J. E. 1993. Population structure of plant pathogenic fungi and bacteria. Adv. Plant Pathol 10:157-205.

22. Olaya, G., and Köller, W. 1999. Baseline sensitivities of Venturia inaequalis populations to the strobilurin fungicide kresoximmethyl. Plant Dis. 83:274-278.

23. Olaya, G., Zheng, D., and Köller, W. 1998. Differential responses of germinating Venturia inaequalis conidia to kresoxim-methyl. Pestic. Sci. 54:230-236.

24. Sauter, H., Ammerman, E., Benoit, R., Brand, S., Gold, R. E., Grammenos, W., Köhl, H., Lorenz, G., Muller, B., Röhl, F., Schirmer, U., Speakman, J. B., Wenderoth, B., and Wingert, H. 1995. Mitochondrial respiration as a target for antifungals: Lessons learned from research on strobilurins. Pages 173-191 in: Antifungal Agents-Discovery and Mode of Action. G. K. Dixon, L. G. Copping, and D. W. Holloman, eds. BIOS, Oxford, UK.

25. Scheinpflug, H., and Kuck, K. H. 1987. Sterol biosynthesis inhibiting piperazine, pyridine, pyrimidine and azole fungicides. Pages $173-$ 204 in: Modern Selective Fungicides-Properties, Applications, and Mechanisms of Action. H. Lyr, ed. John Wiley and Sons, Inc., New York.

26. Sisler, H. D. 1988. Fungicidal action and fungal resistance mechanisms. Pages 6-8 in: Fungicide Resistance in North America. C. J. Delp, ed. APS Press, St. Paul, MN.

27. Smith, F. D., Parker, D. M., and Köller, W. 1991. Sensitivity distribution of Venturia inaequalis to the sterol demethylation inhibitor flusilazole: Baseline sensitivity and implications for resistance monitoring. Phytopathology 81:392-396.

28. Stanghellini, M. E., and Raina, M. 1997. Biosurfactants: Their identity and potential efficacy in the biological control of zoosporic plant pathogens. Plant Dis. 81:4-12. 
29. Suit, R. F. 1948. Effect of copper injury on concord grapes. Phytopathology 38:457-466.

30. Urech, P. A., Staub, T., and Voss, G. 1997. Resistance as a concomitant of modern crop protection. Pestic. Sci. 51:227-234.

31. Von Jagow, G., Gribble, G. W., and Trumpower, B. L. 1986. Mucidin and strobilurin A are identical and inhibit electron transfer in the cytochrome bc-1 complex of the mitochondrial respiratory chain at the same site as myxothiazol. Biochemistry 25:775-780.
32. Wilcox, W. F., and Riegel, D. R. 1998. Evaluation of fungicide programs for control of downy mildew and powdery mildew of grapevine, 1997. Fungic. Nematic. Tests 53:105-106.

33. Wilcox, W. F., Riegel, D. R., and Wong, F. P. 1999. Evaluation of fungicide programs for control of grapevine downy mildew. Fungic. Nematic. Tests 54:111.

34. Ypema, H. L., and Gold, R. E. 1999. Kresoxim-methyl: Modification of a naturally occurring compound to produce a new fungicide. Plant Dis. 83:4-17.

35. Ypema, H. L., Ypema, M., and Gubler, W. D 1997. Sensitivity of Uncinula necator to benomyl, triadimefon, myclobutanil, and fenarimol in California. Plant Dis. 81:293-297.

36. Ziogas, B. N., Baldwin, B. C., and Young, J. E. 1997. Alternative respiration: A biochemical mechanism of resistance to azoxystrobin (ICIA 5504) in Septoria tritici. Pestic. Sci. 50:28-34. 